prolamine protein bodies.

To demonstrate conclusively that storage protein RNA localization was dependent on RNA-based sorting mechanism, we analysed transgenic rice plants expressing a $\beta$-glucuronidase (GUS) reporter gene containing prolamine or glutelin RNA sequences located at the 3' UTR of the gene fusion (Fig. 3). GUS-specific primers were used to detect the hybrid RNA by in situ RT-PCR. No significant fluorescence signals were observed in control plants (Fig. 3a). While GUS transcripts are localized to the PB-ER in GUS::prolamine plants (Fig. 3b), such a distribution pattern was not evident in GUS:: glutelin plants (Fig. 3c). These results confirm the RNA signal dependence of prolamine RNA localization to the PB-ER.

The exact signal domain responsible for localization of prolamine RNAs to the PB-ER has not been identified, but at least part of the sorting determinant resides in the $3^{\prime}$ UTR. Although prolamine peptide sequences are not required, an AUG initiation codon is essential for RNA localization. This latter observation suggests that prolamine RNA moves as a ribonucleoprotein complex containing many components of the protein synthesis machinery especially factors required for translation initiation, that is, ribosome scanning of the initiation codon. Failure to form the translation initiation complex results in RNA mistargeting. As prolamine protein bodies are closely associated with the cortical cytoskeleton ${ }^{9}$, movement of the RNA-translation initiation complex is likely to be mediated by one or more cytoskeletal elements. The transport of ready-to-translate complexes would facilitate the efficient synthesis of large amounts of storage protein on the very restricted PB-ER, a process that probably expedites the formation of the prolamine granule in the ER lumen ${ }^{3}$.

\section{Methods}

\section{T-DNA vector construction and rice transformation}

Synthetic prolamine genes were joined after PCR amplification of prolamine coding (CDS), 3' UTR and glutelin 3' UTR sequences from pProl14, prolamine 4a, and Gt2 genomic sequences respectively ${ }^{10}$. The $\mathrm{HSV}_{\text {or }} \mathrm{His}_{6}$ sequence was added at the end of CDS during PCR. The DNA fragments were inserted downstream of the Gtl promoter, and the promoter-insert fusion was cloned into the T-DNA transformation vector, pCAMBIA1300. Rice (Oryza sativa cv. Kitaake) transformation was performed essentially as described ${ }^{15}$. Transgenic plants were grown in a controlled environment with an 11-hour, $26^{\circ} \mathrm{C}$ day and a 13 -hour, $22^{\circ} \mathrm{C}$ night.

\section{RNA and protein gel blot}

Three micrograms of poly $(\mathrm{A})^{+}$RNA was resolved on a $1 \%$ formaldehyde agarose gel, transferred to a nylon membrane, and hybridized with ${ }^{32} \mathrm{P}$ end-labelled antisense HSV and $\mathrm{His}_{6}$ oligonucleotides. Immunoblot of seed protein extracts were performed with either HSV monoclonal (Novagen) or $\mathrm{His}_{6}$ (Invitrogen) antibody and enhanced chemiluminescence substrates (Pierce).

\section{In situ RT-PCR and reverse transcription}

Cryosections were prepared from 10-14 day old rice seeds, and fixed on glass slides for $30 \mathrm{~min}$ in $2.5 \%$ paraformaldehyde, $1.5 \%$ glutaraldehyde in $50 \mathrm{mM}$ PIPES buffer, $\mathrm{pH} 7.2$ The sections were then washed with phosphate-buffered saline (PBS) for $15 \mathrm{~min}$ followed by water rinses. Fixed sections were overlaid with RT-PCR reaction mixture containing $50 \mathrm{mM}$ Tris- $\mathrm{HCl}, \mathrm{pH} 9.0,20 \mathrm{mM}$ ammonium sulphate, $2.5 \mathrm{mM} \mathrm{MgCl} 2,0.2 \mathrm{mM}$ dATP, dCTP and dGTP, $10 \mu \mathrm{M}$ dTTP, $10 \mu \mathrm{M}$ Oregon Green 488-dUTP or Alexa 594-dUTP (Molecular Probes), $500 \mathrm{U} \mathrm{ml}^{-1} \mathrm{MuLV}$ reverse transcriptase (Stratagene), $50 \mathrm{U} \mathrm{ml}^{-1}$ Thermus thermophilus (Tth) DNA polymerase (Epicentre), and $0.5 \mu \mathrm{M}$ of each primer (5'-CAGCTC GAGCAGCAATGAAG ATCATTTTCGT-3' and 5'-GTCGTAGCCAAGACACCGCCAAGGGTGGTA-3' for prolamine; 5'-GACAAGCTTGTCGGCTTGCGGATAAAGAATAAC- $3^{\prime}$ and $5^{\prime}$-CTGGAATTCTAAACAAATACTACTTAAAGGGGT- $3^{\prime}$ for glutelin; and 5'-CAGCGAAG AGGCAGTCAACGGGGAA-3' and 5'-CATTGTTTGCCTCCCTGCTGCGGTT- $3^{\prime}$ for GUS). The RT-PCR was allowed to proceed at room temperature for $10 \mathrm{~min}$ followed by $60^{\circ} \mathrm{C}$ for $20 \mathrm{~min}$. The seed section was then subjected to 8-10 PCR cycles of $95^{\circ} \mathrm{C}$ for $1 \mathrm{~min}, 72^{\circ} \mathrm{C}$ for $1 \mathrm{~min}$ and $60^{\circ} \mathrm{C}$ for $1 \mathrm{~min}$. In situ reverse transcription was performed for $3 \mathrm{~min}$ at $94^{\circ} \mathrm{C}, 20 \mathrm{~min}$ at $60^{\circ} \mathrm{C}$, and $5 \mathrm{~min}$ at $72^{\circ} \mathrm{C}$ in the reaction solution containing $50 \mathrm{mM}$ Tris- $\mathrm{HCl}, \mathrm{pH} 9.0,20 \mathrm{mM}$ ammonium sulphate,

$1.25 \mathrm{mM} \mathrm{MgCl}_{2}, 1 \mathrm{mM} \mathrm{MnSO}_{4}$, PCR enhancer (Epicentre), $50 \mu \mathrm{M}$ each dATP, dGTP and dCTP, $10 \mu \mathrm{M}$ dTTP, $20 \mu \mathrm{M}$ Oregon Green 488-dUTP, $5 \mathrm{mM}$ dithiothreitol, $150 \mathrm{U} \mathrm{ml}^{-1}$ RNasin (5'-3', Inc.), $50 \mathrm{U} \mathrm{ml}^{-1}$ Tth DNA polymerase and $0.1 \mu \mathrm{M}$ reverse primer $\left(5^{\prime}-\right.$ GTCAAAGCTTAATCCTCGGGGTCTTCCGGGG-3' for HSV-tagged plants; and 5'TCAAGCTTAATGGTGATGGTGATGGTGCAAGA-3' for $\mathrm{His}_{6}$-tagged plants). Sections were stained with rhodamine B hexyl ester (final $0.1 \mu \mathrm{M}), \operatorname{DiOC}_{6}(0.5 \mu \mathrm{M})$ or propidium iodide $(0.5 \mu \mathrm{M})$, and then washed with $2 \times \mathrm{SSC}(0.3 \mathrm{M} \mathrm{NaCl}, 30 \mathrm{mM}$ sodium citrate $)$ for $15 \mathrm{~min}, 0.2 \times \mathrm{SSC}$ for $15 \mathrm{~min}$ twice, and then PBS for at least 10 hours at $4{ }^{\circ} \mathrm{C}$.

Received 30 May; accepted 18 July 2000.

1. Krishnan, H. B., Franceschi, V. R. \& Okita, T. W. Immunochemical studies on the role of the Golgi complex in protein body formation in rice seeds. Planta 169, 471-480 (1986).

2. Yamagata, H. \& Tanaka, K. The site of synthesis and accumulation of rice storage proteins. Plant Cell Physiol. 27, 135-145 (1986).

3. Okita, T. W. \& Rogers, J. C. Compartmentation of proteins in the endomembrane system of plant cells. Annu. Rev. Plant Physiol. \& Plant Mol. Biol. 47, 327-350 (1996).

4. Yamagata, H., Tamura, K., Tanaka, K. \& Kasai, Z. Cell-free synthesis of rice prolamin. Plant Cell Physiol. 27, 1419-1422 (1986).

5. Li, X., Franceschi, V. R. \& Okita, T. W. Segregation of storage protein mRNAs on the rough endoplasmic reticulum membranes of rice endosperm cells. Cell 72, 869-879 (1993).

6. Kim, W. T., Li, X. \& Okita, T. W. Expression of storage protein multigene families in developing rice endosperm. Plant Cell Physiol. 34, 595-603 (1993).

7. Li, X. et al. Rice prolamine protein body biosynthesis: A BiP-mediated process. Science 262, 1054 1056 (1993)

8. Muench, D. G. et al. Molecular cloning, expression and subcellular localization of a BiP homolog from rice endosperm tissue. Plant Cell Physiol. 38, 404-412 (1997).

9. Muench, D. G., Chuong, S. D. X., Franceschi, V. R. \& Okita, T. W. Developing prolamine protein bodies are associated with the cortical cytoskeleton in rice endosperm cells. Planta 211, 227-238 (2000)

10. Kim, W. T. \& Okita, T. W. Structure, expression, and heterogeneity of the rice seed prolamines. Plant Physiol. 88, 649-655 (1988).

11. Mitsukawa, N. \& Tanaka, K. in Rice Genetics II (ed. Khush, G. S.) 503-512 (International Rice Research Institute, Manila, Philippines, 1991).

12. Bassell, G. J., Oleynikov, Y. \& Singer, R. H. The travels of mRNAs through all cells large and small. FASEB J. 13, 447-454 (1999).

13. Jansen, R. P. RNA-cytoskeletal associations. FASEB J. 13, 455-466 (1999).

14. Dalgleish, G. D., Veyrune, J. L., Accornero, N., Blanchard, J. M. \& Hesketh, J. E. Localisation of a reporter transcript by the c-myc 3'-UTR is linked to translation. Nucleic Acids Res. 27, 4363-4368 (1999).

15. Hiei, Y., Ohta, S., Komari, T. \& Kumashiro, T. Efficient transformation of rice (Oryza sativa L.) mediated by Agrobacterium and sequence analysis of the boundaries of the T-DNA. Plant J. 6, 271-282 (1994).

\section{Acknowledgements}

We thank R. S. Boston and F. Takaiwa for providing the maize BiP antibody and prolamine promoter clone. This work was supported in part by United States Department of Agriculture National Research Initiative Competitive Grant Program, by a National Science Foundation Grant, and by Washington State University College of Agriculture and Home Economics Hatch Project.

Correspondence and requests for materials should be addressed to T.W.O. (e-mail: tokita@wsu.edu)

\title{
BcL-2 family proteins regulate the release of apoptogenic cytochrome $c$ by the mitochondrial channel VDAC
}

\section{Shigeomi Shimizu, Masashi Narita \& Yoshihide Tsujimoto}

Nature 399, 483-487 (1999).

Figure 1c of this paper was incorrect. The correct figure is reproduced below.

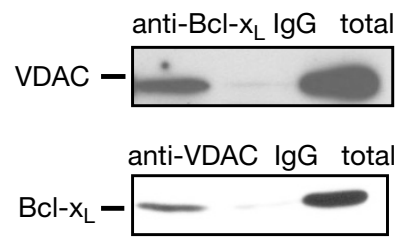


27. Barbet, N., Muriel, W. J. \& Carr, A. M. Versatile shuttle vectors and genomic libraries for use with Schizosaccharomyces pombe. Gene 114, 59-66 (1992).

28. Moreno, S., Klar, A. \& Nurse, P. Molecular genetic analysis of fission yeast Schizosaccharomyces pombe Methods Enzymol. 194, 795-823 (1991).

Acknowledgements. We thank S. O. Sio, Y. Minami and K. Tanaka for comments on the manuscript M. Yanagida and H. Mukai for helpful suggestions, and Y. Kawabe for technical assistance. This work was supported in part by research grants from the Ministry of Education, Science and Culture of Japan.

Correspondence and requests for materials should be addressed to T.K. (tkuno@kobe-u.ac.jp). The nucleotide sequence of Pek1 has been deposited in DDBJ, EMBL and GenBank under accession number D82023.

Bcl-2 family proteins regulate the release of apoptogenic cytochrome $c$ by the mitochondrial channel VDAC

Shigeomi Shimizu*, Masashi Narita \& Yoshihide Tsujimoto*

Osaka University Medical School, Biomedical Research Center, Department of Medical Genetics and ${ }^{*}$ CREST of Japan Science and Technology Corporation (JST), 2-2 Yamadaoka, Suita, Osaka 565-0871, Japan

During transduction of an apoptotic (death) signal into the cell, there is an alteration in the permeability of the membranes of the cell's mitochondria, which causes the translocation of the apoptogenic protein cytochrome $c$ into the cytoplasm, which in turn activates death-driving proteolytic proteins known as caspases ${ }^{1,2}$. The Bcl-2 family of proteins, whose members may be antiapoptotic or pro-apoptotic, regulates cell death by controlling this mitochondrial membrane permeability during apoptosis ${ }^{3-5}$, but how that is achieved is unclear. Here we create liposomes that carry the mitochondrial porin channel (also called the voltagedependent anion channel, or VDAC) to show that the recombinant pro-apoptotic proteins Bax and Bak accelerate the opening of VDAC, whereas the anti-apoptotic protein Bcl- $\mathrm{x}_{\mathrm{L}}$ closes VDAC by binding to it directly. Bax and Bak allow cytochrome $c$ to pass through VDAC out of liposomes, but passage is prevented by Bcl$\mathrm{x}_{\mathrm{L}}$. In agreement with this, VDAC1-deficient mitochondria from a mutant yeast did not exhibit a Bax/Bak-induced loss in membrane potential and cytochrome $c$ release, both of which were inhibited by $\mathrm{Bcl}-\mathrm{x}_{\mathrm{L}}$. Our results indicate that the $\mathrm{Bcl}-2$ family of proteins bind to the VDAC in order to regulate the mitochondrial membrane potential and the release of cytochrome $c$ during apoptosis.

Bax- and Bak-dependent changes in mitochondrial membrane permeability that lead to loss of membrane potential $(\Delta \psi)$ and cytochrome $c$ release ${ }^{6-8}$ are mediated by a polyprotein channel called the permeability transition (PT) pore ${ }^{6,8,9}$, which includes VDAC, the adenine nucleotide translocator (ANT) and cyclophilin D (refs 10, 11). VDAC is an abundant protein in the outer mitochondrial membrane which forms a large voltage-gated pore in planar lipid bilayers $^{12}$, and acts as the pathway for the movement of substances in and out of the mitochondrion. Bax and Bak interact with the PT pore $^{8,9}$. Bax binds to ANT and can sensitize ANT and PT pores in liposomes to atractyloside, an ANT ligand ${ }^{9}$.

During our search for $\mathrm{Bcl}-\mathrm{x}_{\mathrm{L}}$-binding proteins in mitochondria using co-immunoprecipitation with an anti-Bcl- $\mathrm{x}_{\mathrm{L}}$ antibody, we detected three proteins of relative molecular masses $33 \mathrm{~K}, 18 \mathrm{~K}$ and $13 \mathrm{~K}$ (Fig. 1a). Partial amino-acid sequencing of the $33 \mathrm{~K}$ protein revealed a match with rat VDAC. Co-immunoprecipitation followed by western blot analysis confirmed the interaction between $\mathrm{Bcl}-\mathrm{x}_{\mathrm{L}}$ and VDAC in isolated mitochondria (Fig. 1b) and also in Bcl$\mathrm{x}_{\mathrm{L}}$-expressing HepG2 cells (Fig. 1c). No co-immunoprecipitable interaction of Bcl- $\mathrm{x}_{\mathrm{L}}$ with Tom 40 (an integral outer-membrane protein) or with $\mathrm{F}_{1}$-ATPase (an inner-membrane protein) was detected (data not shown), indicating that the interaction between $\mathrm{Bcl}-\mathrm{x}_{\mathrm{L}}$ and VDAC was specific. As the PT pore is a polyprotein a

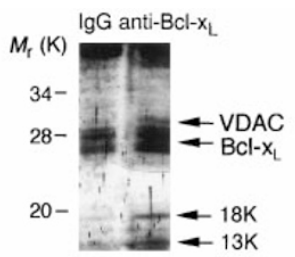

$\mathbf{c}$

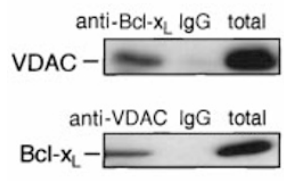

b

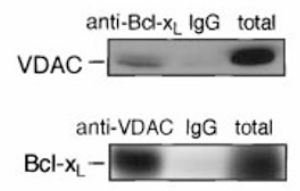

d

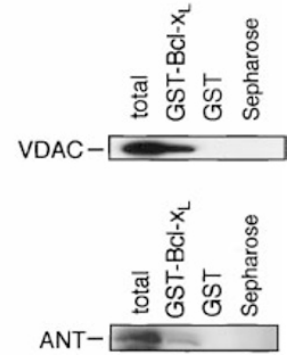

Figure 1 Interaction of $\mathrm{Bcl}-\mathrm{x}_{\mathrm{L}}$ with VDAC. $\mathbf{a}, \mathrm{Bcl}-\mathrm{x}_{\mathrm{L}}$-binding proteins. Rat liver mitochondria $\left(1 \mathrm{mg} \mathrm{ml}^{-1}\right)$ were incubated with $\mathrm{rBcl}-\mathrm{x}_{\mathrm{L}}\left(20 \mathrm{mg} \mathrm{ml}^{-1}\right)$ for $5 \mathrm{~min}$ and their lysates were immunoprecipitated with anti-Bcl- $x_{L}$ antibody or rabbit IgG. Immune complexes were analysed by SDS-PAGE and silver staining. b, Interaction of $\mathrm{rBCl}-\mathrm{x}_{\mathrm{L}}$ with VDAC in mitochondria. Mitochondria were incubated with $r B c l-X_{L}$, lysed and immunoprecipitated as in $\mathbf{a}$, but also with anti-VDAC monoclonal antibody or normal mouse IgG. Anti-VDAC and anti-BCl- $x_{L}$ antibodies were used for western blotting. An aliquot of mitochondria (total) was used as the control. c, Interaction of $r B c l-x_{L}$ with VDAC in HepG2 cells. Lysates of human Bcl$\mathrm{X}_{\mathrm{L}}$-expressing HepG2 cells were immunoprecipitated as for $\mathbf{b}$. $\mathbf{d}$, Direct interaction between Bcl- $x_{L}$ and VDAC or ANT. (See Methods for details.) Bound VDAC and ANT were analysed by western blotting; 'total' represents the amount of each protein used.

channel that includes VDAC, co-immunoprecipitation of $\mathrm{Bcl}-\mathrm{x}_{\mathrm{L}}$ and VDAC from the mitochondria and cells did not necessarily indicate their direct interaction. VDAC purified from rat liver mitochondria efficiently bound to a fusion protein between glutathione- $S$-transferase and $\mathrm{Bcl}-\mathrm{x}_{\mathrm{L}}\left(\mathrm{GST}-\mathrm{Bcl}-\mathrm{x}_{\mathrm{L}}\right)$, however, indicating that $\mathrm{Bcl}-\mathrm{x}_{\mathrm{L}}$ interacted directly with $\mathrm{VDAC}$; similar results were obtained when recombinant VDAC was used (data not shown). ANT purified from rat heart bound only weakly to GST$\mathrm{Bcl}-\mathrm{x}_{\mathrm{L}}$ (Fig. 1d), consistent with earlier observations ${ }^{9}$.

As $\mathrm{Bcl}-\mathrm{x}_{\mathrm{L}}$ binds VDAC, we tested the effect of $\mathrm{Bcl}-\mathrm{x}_{\mathrm{L}}$ on VDAC activity by using VDAC purified from rat liver mitochondria and reconstituted into liposomes. These VDAC liposomes could take up radiolabelled sucrose, whereas plain or heat-denatured VDACcontaining liposomes could not; uptake was greatly reduced in VDAC liposomes preincubated with a polyanion VDAC inhibitor (Fig. 2a), indicating that this sucrose uptake must be mediated by VDAC. Addition of recombinant $(\mathrm{r}) \mathrm{Bcl}-\mathrm{x}_{\mathrm{L}}$ to VDAC liposomes inhibited VDAC-mediated sucrose uptake in a $\mathrm{pH}$-dependent manner (Fig. 2b): Bcl- $\mathrm{x}_{\mathrm{L}}$ functioned at acidic $\mathrm{pH}$, consistent with observations that $\mathrm{rBcl}^{-\mathrm{x}_{\mathrm{L}}}$ acts as an ion channel in synthetic lipid membranes only under acidic conditions ${ }^{13-16}$. However, when both $\mathrm{rBcl}-\mathrm{x}_{\mathrm{L}}$ and VDAC were incorporated together into liposomes, Bcl$\mathrm{x}_{\mathrm{L}}$ was able to function at $\mathrm{pH} 7.3$ (Fig. 2c), suggesting that incorporation of $\mathrm{Bcl}-\mathrm{x}_{\mathrm{L}}$ into the lipid membranes was favoured at lower $\mathrm{pH}$. Although the VDAC has been reported to close below $\mathrm{pH}$ 5.0 (ref. 22), our VDAC liposomes showed no difference in behaviour between $\mathrm{pH} 5.2$ and 7.3 (data not shown). VDAC was inhibited by $\mathrm{rBcl}-\mathrm{x}_{\mathrm{L}}$ in a concentration-dependent manner (Fig. 2d), and two Bcl- $\mathrm{x}_{\mathrm{L}}$ mutants (mt-1; F131V, D133A; mt-7; VNW at 135137 changed to AIL) having partial and no anti-apoptotic activity, respectively ${ }^{17}$, gave partial and no inhibition of VDAC-mediated sucrose uptake (Fig. 2d), indicating that those two activities could be linked. As shown in Fig. 2e, mt-1 and mt-7, respectively, bound 
VDAC weakly and not at all, indicating that the inhibition of VDAC by $\mathrm{Bcl}-\mathrm{x}_{\mathrm{L}}$ depends on $\mathrm{Bcl}-\mathrm{x}_{\mathrm{L}}$ binding to VDAC. VDAC was also inhibited by $\mathrm{Bcl}-\mathrm{x}_{\mathrm{L}}$ in VDAC liposomes made with recombinant VDAC (Fig. 2f), confirming that VDAC is targeted by Bcl- $\mathrm{x}_{\mathrm{L}}$.

We next tested the effect of Bax on VDAC activity and found that rBax enhanced VDAC-mediated sucrose uptake at pH 5.2 (Fig. 3a), but that uptake of sucrose into plain liposomes incorporating Bax but without VDAC was low (Fig. 3a), indicating that the rBaxenhanced sucrose uptake by VDAC liposomes is mediated not by a putative Bax channel but by the effect of Bax on VDAC. We confirmed this by adding polyanion in the presence of Bax to VDAC liposomes, which significantly inhibited sucrose uptake a

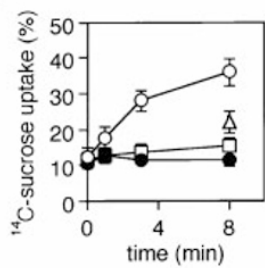

c

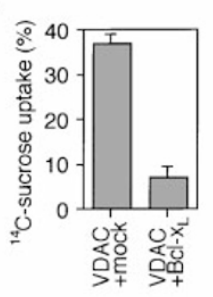

$\mathbf{e}$

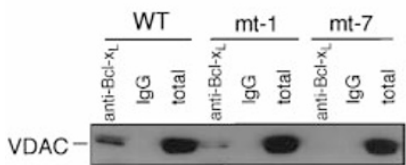

d
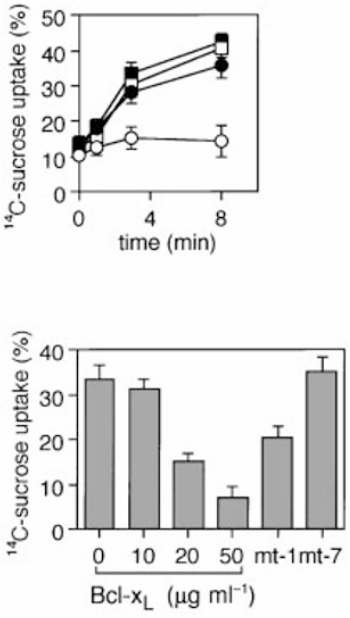

$\mathbf{f}$

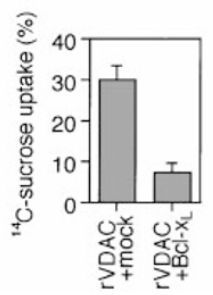

Figure 2 Inhibition of VDAC activity by Bcl- $x_{L}$ in VDAC liposomes. a, Sucrose uptake by VDAC liposomes. Plain liposomes (filled circles), VDAC liposomes (open circles), heat-denaturated VDAC liposomes (open squares), and VDAC liposomes with polyanion $\left(100 \mu \mathrm{g} \mathrm{ml}^{-1}\right.$ ) (open triangle) were incubated with ${ }^{14} \mathrm{C}$ sucrose for the identicated times at pH 5.2 (see Methods). Liposomes were recovered, dissolved in $2 \%$ SDS and their ${ }^{14} \mathrm{C}$-sucrose content counted. b, Inhibition of VDAC activity in VDAC liposomes by Bcl-X $\mathrm{L}$. VDAC liposomes were incubated with ${ }^{14} \mathrm{C}$-sucrose and either $\mathrm{rBcl}-\mathrm{x}_{\mathrm{L}}\left(20 \mu \mathrm{g} \mathrm{ml}^{-1}\right)$ (open symbols) or mock protein (filled symbols) at pH 5.2 (circles) and $\mathrm{pH} 7.3$ (squares), and ${ }^{14} \mathrm{C}$-sucrose uptake was measured (see Methods). c, Inhibition of VDAC activity by $\mathrm{Bcl}-\mathrm{x}_{\mathrm{L}}$ at neutral $\mathrm{pH}$ in liposomes containing VDAC and $r B C l-x_{L}$. Purified VDAC and $r B c l-x_{L}$ were both embedded together into liposomes (see Methods), which were then incubated with ${ }^{14} \mathrm{C}$-sucrose at $\mathrm{pH} 7.3$ for 3 min and their ${ }^{14} \mathrm{C}$-sucrose uptake measured. d, Inhibition of VDAC activity by Bcl- $x_{L}$ in a dose-dependent manner and effect of $\mathrm{Bcl}-\mathrm{x}_{\mathrm{L}}$ mutants. VDAC liposomes were incubated with ${ }^{14} \mathrm{C}$-sucrose and $\mathrm{rBcl}-\mathrm{x}_{\mathrm{L}}, \mathrm{rBcl}-\mathrm{x}_{\mathrm{L}}$ mutant $\mathrm{mt}-1$ or $\mathrm{mt}-7$ protein at $20 \mu \mathrm{g} \mathrm{ml}^{-1}$ at $\mathrm{pH} 5.2$ for $3 \mathrm{~min}$, and ${ }^{14} \mathrm{C}$-sucrose uptake was measured. e, Interaction of $\mathrm{BCl}-\mathrm{x}_{\mathrm{L}}$ mutants with VDAC. Experiments as in Fig. $1 \mathrm{~b}$ were done using $r B c l-x_{L}$ and $r B c l-x_{L}$ mutants $m t-1$ and $m t-7$. Mitochondrial lysates immunoprecipitated with anti-Bcl- $x_{L}$ antibody or rabbit IgG were western-blotted with anti-VDAC antibody. WT, wild type. $\mathbf{f}$, Inhibition of VDAC activity by $\mathrm{BCl}-\mathrm{x}_{\mathrm{L}}$ in liposomes incorporating recombinant VDAC. VDAC liposomes were incubated with ${ }^{14} \mathrm{C}$-sucrose and $\mathrm{rBcl}-\mathrm{x}_{\mathrm{L}}$ at $\mathrm{pH} 5.2$ for 3 min and their ${ }^{14} \mathrm{C}$-sucrose uptake measured.
(Fig. 3a). As the interaction of VDAC and Bax was not inhibited by polyanion (data not shown), and as polyanion inhibited VDAC activity (Fig. 2a) but not Bax channel activity, as assessed by movement of rhodamine 123 (data not shown), we conclude that Bax enhances VDAC activity. Results were similar for VDAC liposomes made with recombinant VDAC, and when pro-apoptotic Bak (lacking the C-terminal 21 amino-acid residues) was used in place of rBax (Fig. 3b). With liposomes containing both rBax and VDAC, Bax could function at pH 7.3 (data not shown). Consistent with the effect of Bax and Bak on VDAC activity, rBax and rBak could bind purified VDAC (Fig. 3c). Binding between endogenous Bax and VDAC occurred in apoptotic but not intact PC12 cells a

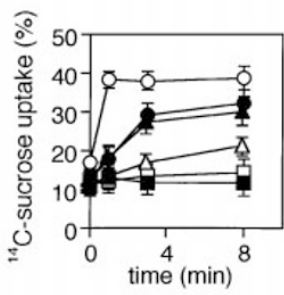

$\mathbf{c}$

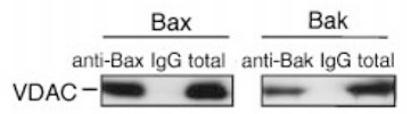

$\mathbf{e}$

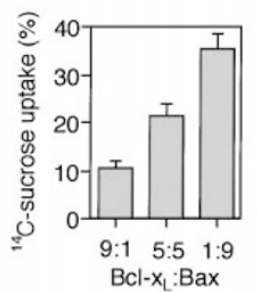

b

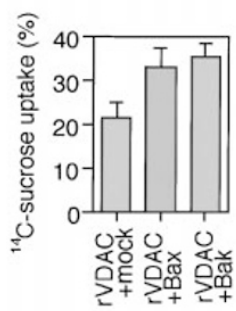

d

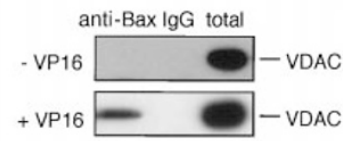

f

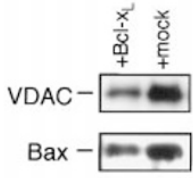

Figure 3 Enhancement of VDAC activity by Bax as well as its inhibition by $\mathrm{Bcl}-\mathrm{X}_{\mathrm{L}} \cdot \mathbf{a}$, ${ }^{14} \mathrm{C}$-sucrose uptake into VDAC liposomes is enhanced by Bax. Plain liposomes (squares) and VDAC liposomes (circles and triangles) were incubated with ${ }^{14} \mathrm{C}$ sucrose, rBax $\left(20 \mu \mathrm{g} \mathrm{ml}^{-1}\right.$ ) (open circles and open squares), rBax $\left(20 \mu \mathrm{g} \mathrm{ml}^{-1}\right)$ and polyanion (100 $\mathrm{g} \mathrm{ml}^{-1}$ ) (open triangles), rBax $\Delta \mathrm{BH} 3\left(20 \mu \mathrm{g} \mathrm{ml}^{-1}\right)$ (filled triangles), and mock protein (filled circles and filled squares) at $\mathrm{pH} 5.2$ for the indicated times before measuring ${ }^{14} \mathrm{C}$-sucrose uptake. b, VDAC activity is increased by Bax and Bak in liposomes incorporating recombinant VDAC. VDAC liposomes were incubated with ${ }^{14} \mathrm{C}$-sucrose and with rBax, rBak or mock protein at $\mathrm{pH} 5.2$ as in $\mathbf{a}$ and the ${ }^{14} \mathrm{C}$-sucrose uptake was counted at 3 min. c. Direct interaction of Bax and Bak with VDAC. VDAC liposomes preincubated with rBax or rBak were immunoprecipitated with anti-Bax or anti-Bak antibodies or with rabbit IgG and western-blotted with anti-VDAC antibody. An aliquot of the initial mixture (total) was used as control. d, Interaction of endogenous Bax with endogenous VDAC in PC12 cells. Lysates from PC12 cells (a rat pheochromocytoma cell line) preincubated with or without $50 \mu \mathrm{M}$ VP16 for $12 \mathrm{~h}$ were immunoprecipitated with either an anti-mouse Bax antibody that crossreacts with rat Bax or rabbit lgG and the immune complexes western-blotted as in $\mathbf{c}$. e. Antagonism of sucrose import into VDAC liposomes by Bax and $\mathrm{Bcl}-\mathrm{X}_{\mathrm{L}}$. VDAC liposomes were incubated with ${ }^{14} \mathrm{C}$-sucrose and with $\mathrm{rBax}$ and $\mathrm{rBcl}-\mathrm{x}_{\mathrm{L}}$ at the indicated ratios (total $20 \mu \mathrm{g} \mathrm{ml}^{-1}$ ) at $\mathrm{pH}$ 5.2, and ${ }^{14} \mathrm{C}$-sucrose uptake measured at $3 \mathrm{~min}$. $\mathbf{f}$, Inhibition of interaction with Bax and VDAC by Bcl-X $x_{L}$. VDAC liposomes incubated with $\mathrm{BCl}-\mathrm{X}_{\mathrm{L}}$ or mock protein for $5 \mathrm{~min}$, then with $\mathrm{rBax}$ (all at $20 \mu \mathrm{g} \mathrm{ml}^{-1}$ ) for $5 \mathrm{~min}$, were immunoprecipitated with anti-Bax (top) or anti-VDAC (bottom) antibodies and western-blotted with anti-Bax or anti-VDAC antibody. 
(Fig. 3d). $\mathrm{rBax}$ and $\mathrm{rBcl}-\mathrm{x}_{\mathrm{L}}$ were antagonistic towards VDAC (Fig. 3e). As preincubation of VDAC liposomes with $\mathrm{Bcl}-\mathrm{x}_{\mathrm{L}}$ significantly inhibited $\mathrm{rBax}$ binding to VDAC (Fig. 3f), the effect on VDAC activity of $\mathrm{Bax}$ and $\mathrm{Bcl}-\mathrm{x}_{\mathrm{L}}$ was regulated by their competitive binding to VDAC and their heterodimerization. A recombinant mutant Bax lacking its $\mathrm{BH} 3$ region had no effect on VDAC (Fig. 3a), indicating that this region is necessary for enhancing VDAC activity, consistent with our previous observation that the $\mathrm{BH} 3$ region is essential for Bak-induced mitochondrial changes ${ }^{8}$. We found that VDAC preparations from rat liver did not contain detectable ANT, as assessed by western blotting, and that sucrose uptake by VDAC liposomes was unaffected by the two ANT ligands atractyloside and bongkrekic acid (data not shown), indicating that we had no contamination by ANT in our VDAC preparations.

a

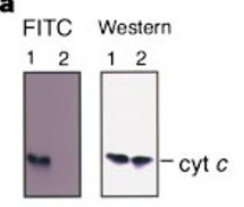

b
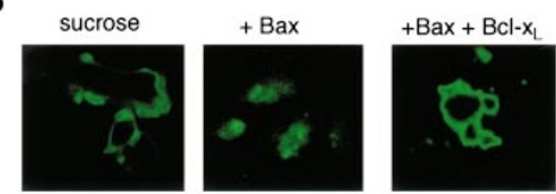

c
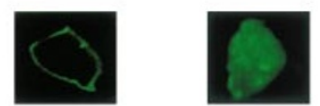

Plain

liposome

$100 \%$

$0 \%$

VDAC

liposome

VDAC

liposome

+ Bax

VDAC

liposome

+ Bax+polyanion

VDAC

liposome

$+\mathrm{Bax}+\mathrm{Bcl}-\mathrm{x}_{\mathrm{L}}$

$100 \%$

$0 \%$

$9 \%$

$78 \%$

$91 \%$

d
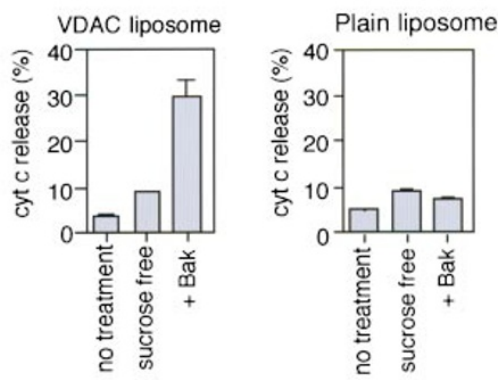

Figure 4 Induction of cytochrome $c$ movement through VDAC by Bax and Bak. a, FITC labelled cytochrome $c$ was run on SDS-PAGE (see Methods) and was detected by fluorescence (left) and western blotting with anti-cytochrome $C$ antibody (right): lane 1, FITC-cytochrome $c(25 \mathrm{pg})$; lane 2, cytochrome $c$ $(25 \mathrm{pg})$. b, c, Bax-induced import of FITC-cytochrome $c$ into VDAC liposomes. $\operatorname{VDAC}$ liposomes $(\mathbf{b}, \mathbf{c})$ and plain liposomes (c) were incubated with FITCcytochrome $c$ and sucrose $(50 \mathrm{mM})$, plus $\operatorname{rBax}\left(52 \mu \mathrm{g} \mathrm{ml}^{-1}\right), \mathrm{rBax}\left(52 \mu \mathrm{g} \mathrm{ml}^{-1}\right)$ and polyanion $\left(100 \mu \mathrm{g} \mathrm{ml}^{-1}\right.$ ), rBax and $\mathrm{rBcl}^{-x_{\mathrm{L}}}$ (both at $52 \mu \mathrm{g} \mathrm{ml}^{-1}$ ), or without any of these at pH 5.2 for 5 min (see Methods), and were observed under a confocal fluorescence microscope. Representative photographs (original magnification, $\times 4,800$ ) of VDAC-liposomes are shown in $\mathbf{b}$. In $\mathbf{c}$, the frequency (given as a percentage) and representative photographs of liposomes with and without influxed cytochrome $c$ are shown (original magnification, $x 10,000$ ). d, Bak-induced cytochrome $c$ release form VDAC liposomes. Plain or VDAC liposomes containing $80 \mathrm{mM}$ sucrose and $0.5 \mathrm{mM}$ cytochrome $c$ were incubated in sucrose-free buffer with or without rBak for $30 \mathrm{~min}$ at $\mathrm{pH} 5.2$ (see Methods). The release of cytochrome $c$ was quantified spectrophotometrically (total incorporated cytochrome $c$ is $100 \%)$
As Bax and Bak induce cytochrome $c$ release through PT pores of isolated mitochondria ${ }^{6-8}$ and as they enhance VDAC activity, we investigated whether cytochrome $c$ could pass through VDAC in the presence of Bax and Bak. To monitor the movement of cytochrome $c$ microscopically, we incubated fluorescein isothiocyanate (FITC)labelled cytochrome $c$ (Fig. 4a) with VDAC liposomes. In the absence of $\mathrm{rBax}$, cytochrome $c$ accumulated on the surfaces of plain and VDAC liposomes (Fig. 4b, c), but in the presence of $\mathrm{rBax}$ (Fig. 4b, c) or rBak (data not shown), cytochrome $c$ accumulated inside VDAC liposomes (Fig. 4b, c). Also, polyanion significantly inhibited Bax-induced cytochrome $c$ movement (Fig. 4c), indicating that Bax and Bak allowed cytochrome $c$ to pass through VDAC. Bax-induced movement of cytochrome $c$ was inhibited in the presence of $\mathrm{rBcl}^{-\mathrm{x}_{\mathrm{L}}}$ (Fig. $4 \mathrm{~b}, \mathrm{c}$ ). When cytochrome $c$ and sucrose were initially incorporated inside VDAC liposomes, and the liposomes were then incubated with buffer, a significant amount of cytochrome $c$ was released only in the presence of $\mathrm{rBak}$ (Fig. $4 \mathrm{~d}$ ) and $\operatorname{rBax}$ (data not shown); cytochrome $c$ was not released by plain liposomes in the presence of rBak (Fig. 4d). Bax/Bak-dependent passage of cytochrome $c$ through VDAC occurred also in the absence of sucrose (data not shown). During these experiments, the number of liposomes did not change, as assessed by flow cytometry (data not shown), and a GST-GFP (green fluorescence protein) fusion protein $\left(M_{\mathrm{r}}=50 \mathrm{~K}\right)$ was not released when $\mathrm{rBax}$ was added to VDAC liposomes containing GST-GFP (data not shown), indicating that the liposomes did not rupture and that Bax and Bak enable cytochrome $c$ to pass through VDAC.

Our results indicate that $\mathrm{Bcl}-2$ family proteins may target VDAC directly in order to modulate channel activity. We therefore investigated whether VDAC could be a target for Bcl-2 family proteins that are involved in regulating the apoptosis-associated loss of mitochondrial membrane potential $(\Delta \psi)$ and the release of cytochrome $c$. As no mammalian cells lacking VDAC were available and because Bcl-2 family proteins can function in yeast cells ${ }^{18,19}$, we used a yeast mutant deficient in VDAC1 $(\Delta \text { VDAC })^{20}$ and found that mitochondria isolated from the wild-type yeast lost $\Delta \psi$ and released cytochrome $c$ after addition of $\mathrm{rBax}$ in a dose-dependent manner (Fig. 5a, d) like mammalian mitochondria, whereas rBax did not cause a loss of $\Delta \psi$ and cytochrome $c$ release in mitochondria isolated from $\triangle$ VDAC yeast cells (Fig. 5b, d). However, rBax did induce both effects in mitochondria from $\triangle$ VDAC yeast transfected with the human (h) vdac1 gene (Fig. 5c, d), indicating that the failure of $\triangle$ VDAC yeast mitochondria to respond to $\mathrm{rBax}$ was due to the absence of functional VDAC. Bax-mediated $\Delta \psi$ loss and cytochrome $c$ release in yeast mitochondria were inhibited by $\mathrm{rBcl}_{-\mathrm{x}_{\mathrm{L}}}$ (Fig. 5a, c, d). Results were similar when rBak was used (Fig. 5a-c, and data not shown). These results indicate that Bcl-2 family proteins target VDAC to regulate apoptosis-associated mitochondrial loss of $\Delta \psi$ and release of cytochrome $c$.

The fact that Bax and Bak enable cytochrome $c$ to pass through VDAC, whereas Bcl- $\mathrm{x}_{\mathrm{L}}$ does not, may explain how cytochrome $c$ is released during apoptosis. We used the VDAC1-deficient yeast mutant ${ }^{20}$ to show that VDAC is essential for Bax/Bak-induced mitochondrial $\Delta \psi$ loss and cytochrome $c$ release. Although yeast cells carry VDAC1 and VDAC2, VDAC2 makes only a small contribution to the membrane permeability to metabolites. ${ }^{21}$ Extrapolation of these observations suggests that VDAC is essential for cytochrome $c$ release during apoptosis of mammalian cells. The estimated size of the VDAC pore is $\sim 2.6 \mathrm{~nm}$, which is not large enough for folded cytochrome $c$ with a similar diameter to pass through $\mathrm{VDAC}^{22}$; indeed, VDAC liposomes did not allow the passage of cytochrome $c$ (Fig. 4). Therefore Bax/Bak probably induces a conformational change in VDAC so that cytochrome $c$ can pass through the channel, although it is possible that Bax/Bak and VDAC could together form a larger channel, and other unknown mechanisms may contribute to apoptotic cytochrome $c$ release in vivo. 


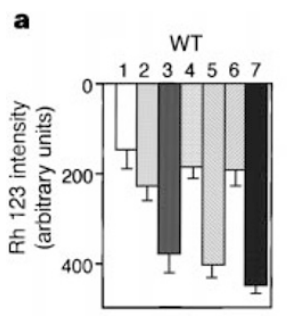

b
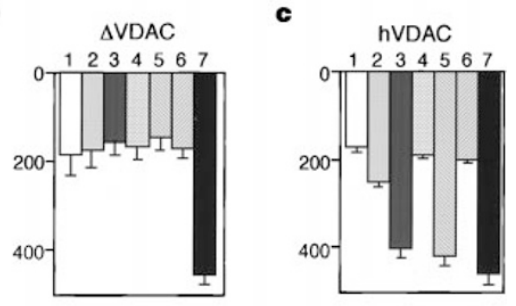

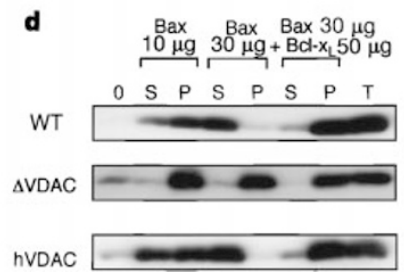

Figure 5 Requirement of VDAC for Bax/Bak-induced loss of membrane potential and cytochrome $c$ release in yeast mitochondria. a-c, Inability of VDAC-deficient mitochondria to show rBax/rBak-induced loss of membrane potential. Mitochondria $\left(1.0 \mathrm{mg} \mathrm{m}^{-1}\right.$ ) isolated from wild-type (WT) yeast (a), VDAC1-deficient yeast $(\triangle \mathrm{VDAC})(\mathbf{b})$, or human VDAC1-expressing $\triangle \mathrm{VDAC}$ (hVDAC) (c) yeast were incubated with: lane 2, $10 \mu \mathrm{g} \mathrm{ml}^{-1}$, and lanes 3, 4, $30 \mu \mathrm{g} \mathrm{ml}^{-1}$ rBax; lanes 5, 6, $30 \mu \mathrm{g} \mathrm{ml}^{-1} \mathrm{rBak}$; lane 1, mock, in the presence (lanes 4, 6) or absence (lanes 3, 5) of $50 \mu \mathrm{g} \mathrm{ml}^{-1}$ of Bcl-X for $10 \mathrm{~min}$, and $\Delta \psi$ was measured by rhodamine (Rh) 123 intensity; lane 7 , complete loss of $\Delta \psi$ was demonstrated by incubation of

Bax and Bcl-2 have been shown to interact with ANT and Bax to sensitize ANT to its atractyloside ligand in ANT liposomes and in partially purified PT-pore liposomes ${ }^{9}$. However, Bax did not affect mitochondrial ADP uptake, which is mediated by ANT (our unpublished observations). Therefore Bax might modulate ANT activity after binding under certain circumstances, but our results strongly indicate that VDAC is a functional target for Bcl-2 family proteins. As Bax/Bak induces loss of $\Delta \psi$ across the inner membrane in mitochondria and as the PT pore is a polyprotein channel, the Bax/Bak-mediated conformational change of VDAC probably affects other channels in the PT pore that control inner-membrane permeability. Alternatively, interaction of Bax/Bak with ANT or ANT-related channels in the inner membrane might be directly involved in $\Delta \psi$ collapse. As PT inhibitors such as cyclosporin $\mathrm{A}$ and bongkrekic acid can inhibit Bax/Bak-induced cytochrome $c$ release in isolated mitochondria ${ }^{6,8}, \mathrm{VDAC}$-mediated cytochrome $c$ release could be controlled not only by Bcl-2 family proteins but also by other components of the PT pore such as ANT (a target of bongkrekic acid) and cyclophilin D (a target of cyclosporin A). Thus, various components of the PT pore seem to interact with each other. The interaction of $\mathrm{Bcl}-\mathrm{x}_{\mathrm{L}}$ and Bax with ANT may direct these molecules to bind antagonistically with VDAC inside the PT pore rather than with VDAC in isolation.

Taken together, our results indicate that the Bcl-2 family of proteins target VDAC to regulate apoptosis-associated mitochondrial changes that are central to determining the survival or death of cells.

\section{Methods}

Antibodies. Anti-pigeon cytochrome $c$ monoclonal antibody (7H8.2C12), anti-yeast cytochrome $c$ polyclonal antibody and anti-rat ANT polyclonal antibody were kindly provided by E. Margoliash, G. Shatz and H. H. Schmid, respectively. Anti-human VDAC monoclonal antibody $(31 \mathrm{HL})$, which crossreacts with rat VDAC, was from Calbiochem. Anti-human $\mathrm{Bcl}-\mathrm{x}_{\mathrm{L}}$ (L19), antihuman Bak (G23) and anti-human Bax (N20) polyclonal antibodies were from Santa Cruz Biotechnology.

Immunoprecipitation and western blot analysis. Rat liver mitochondria were isolated as described ${ }^{23}$. Immunoprecipitation was done as described ${ }^{8}$ using cells, mitochondria and liposomes lysed and sonicated in lysis buffer $(10 \mathrm{mM}$ mitochondria with $1 \mathrm{mM}$ CCCP for $10 \mathrm{~min}$. d, Failure of VDAC1-deficient mitochondria to show Bax-induced cytochrome $c$ release. Mitochondria $\left(1 \mathrm{mg} \mathrm{m}^{-1}\right)$ isolated from wild-type, $\triangle \mathrm{VDAC}$ or hVDAC1-expressing $\triangle \mathrm{VDAC}$ yeasts (hVDAC) were incubated with $\mathrm{rBax}\left(10\right.$ and $30 \mu \mathrm{g} \mathrm{ml}^{-1}$ ) either with or without $\mathrm{rBcl}-\mathrm{X}_{\mathrm{L}}\left(50 \mu \mathrm{g} \mathrm{ml}^{-1}\right)$ for $10 \mathrm{~min}$, then centrifuged: supernatants $(\mathrm{S})$ and pellets $(P)$ were western-blotted with anti-yeast cytochrome $c$ antibody. ' $O$ ', Supernatant of mitochondria before treatment; ' $T$ ', unspun mitochondria . Data are representative of three independent experiments.

HEPES, pH 7.4, $142.5 \mathrm{mM} \mathrm{KCl,} 5 \mathrm{mM} \mathrm{MgCl}_{2}, 1 \mathrm{mM}$ EGTA, 0.5\% N-P40) containing proteinase inhibitors. To detect binding between purified proteins, $\operatorname{VDAC}(0.2 \mu \mathrm{g})$ and ANT $(0.2 \mu \mathrm{g})$ were incubated for $3 \mathrm{~h}$ either with GST-Bcl$\mathrm{x}_{\mathrm{L}}(0.2 \mu \mathrm{g})$ or GST $(0.2 \mu \mathrm{g})$ in $100 \mu \mathrm{l}$ of the lysis buffer. Then, these proteins were incubated with glutathione (GSH)-Sepharose or Sepharose for $3 \mathrm{~h}$. After brief centrifugation, beads were washed and resuspended in sample buffer for SDS-PAGE.

Protein purification. Human Bcl- $\mathrm{x}_{\mathrm{L}}$, two Bcl- $\mathrm{x}_{\mathrm{L}}$ mutants, human Bak (lacking the C-terminal 21 amino-acid residues), human Bax, Bax lacking the BH3 region $(\mathrm{Bax} \Delta \mathrm{BH} 3)$, and mock proteins were produced and purified as described $^{8}$. Haemagglutinin (HA)-tagged human VDAC1 was expressed in Escherichia coli strain DE3 using the Xpress System (Invitrogen) and purified on an HA column. All proteins except for VDAC were dissolved in $10 \mathrm{mM}$ HEPES- $\mathrm{K}^{+}$( $\left.\mathrm{pH} 7.4\right)$ with $1 \mathrm{mM}$ DTT, and VDAC was in VDAC buffer $(10 \mathrm{mM}$ Tris-Cl, pH 7.0, 1 mM EDTA, and 3\% Triton-X100).

Rat liver VDAC was purified as described ${ }^{24}$. Rat heart ANT was purified as described $^{25}$. The purity of VDAC and ANT was shown to be $>95 \%$.

Reconstitution of VDAC in liposomes. Purified and recombinant VDAC were reconstituted in small unilamelar vesicles by a modification of the sonic freezethaw procedure ${ }^{26}$. Briefly, $100 \mathrm{mg}$ phospholipid (soybean, type II-S) was dissolved into $1 \mathrm{ml}$ liposome medium containing $30 \mathrm{mM}$ sodium sulphonate and $20 \mathrm{mM}$ Tricine- $\mathrm{NaOH}$ ( $\mathrm{pH} 7.3$ or $\mathrm{pH} 5.2$ ) with or without $80 \mathrm{mM}$ sucrose. After sonication, purified or recombinant VDAC protein $(200 \mu \mathrm{g})$ was added with or without $\mathrm{rBcl}^{-x_{\mathrm{L}}}(200 \mu \mathrm{g})$ and $\mathrm{rBax}(200 \mu \mathrm{g})$, and this suspension was subjected to two freeze-thaw cycles. Heat-denatured VDAC protein was obtained by heating at $95^{\circ} \mathrm{C}$ for $10 \mathrm{~min}$. Then unilamelar VDAC liposomes were produced by mild sonication and fractionated on Sephadex G-50 columns. Light scattering from each fraction was measured spectrophotometrically at $520 \mathrm{~nm}$, and the fraction containing 700-900 arbitrary units per $\mu \mathrm{l}$ was used.

A sucrose-import experiment was performed by measuring ${ }^{14} \mathrm{C}$-sucrose uptake. Liposomes $(10 \mu \mathrm{l})$ were incubated with $5 \mu \mathrm{l}{ }^{14} \mathrm{C}$-sucrose $(97 \%$; $200 \mu \mathrm{Ci} \mathrm{ml}^{-1}$ ) at $25^{\circ} \mathrm{C}$ and filtered by centrifugation using a $30 \mathrm{~K}$ limiting filter (Millipore) to remove free ${ }^{14} \mathrm{C}$-sucrose; incorporated ${ }^{14} \mathrm{C}$-sucrose was measured in a gamma-scintillation counter (Wallac 1414).

Cytochrome $c$ translocation experiment. FITC-labelled cytochrome $c$ was produced as described ${ }^{27}$ : the FITC/cytochrome $c$ molar ratio was 0.47 . FITClabelled cytochrome $c$ was detected with a lumino-image analyser (LAS-1000, Fujifilm). Liposomes $(2 \mu \mathrm{l})$ were incubated with both sucrose $(50 \mathrm{mM})$ and 
FITC-labelled cytochrome $c(50 \mu \mathrm{M})$ and various proteins in a total volume of $29 \mu \mathrm{l}$ at $\mathrm{pH}$ 5.2; labelled cytochrome $c$ was visualized using confocal microphotography (LSM-745, Olympus).

For cytochrome $c$ export, liposomes $(1 \mathrm{ml})$ in sucrose $(80 \mathrm{mM})$-containing buffer were mixed with cytochrome $c(100 \mu \mathrm{M})$ and freeze-thawed for two cycles. After unilamerization, $20 \mu \mathrm{l}$ liposomes were incubated with $1 \mathrm{ml}$ sucrose-free buffer with or without $20 \mu \mathrm{g} \mathrm{ml}^{-1} \mathrm{rBak}$ for $10 \mathrm{~min}$ at $25^{\circ} \mathrm{C}$, then filtered by centrifugation through a $30 \mathrm{~K}$ filter to separate liposomes from free cytochrome $c$. Free cytochrome $c$ was determined from the absorbance at $408 \mathrm{~nm}$.

Yeast mitochondria. AVDAC1-deficient yeast strain ( $\triangle$ VDAC; M22-2) and its parent strain (M3) were used. A human VDAC1-expressing $\triangle$ VDAC yeast strain was produced by transfecting human $v d a c l$ cDNA using lithium acetate. Mitochondria were isolated essentially as described ${ }^{28}$, using zymolyase $20 \mathrm{~T}$ to form spheroplasts which were then homogenized. Isolated mitochondria were suspended in $0.3 \mathrm{M}$ mannitol, $10 \mathrm{mM}$ Tris-maleiate ( $\mathrm{pH}$ 7.4), $0.2 \mathrm{mM}$ EDTA, $0.05 \% \mathrm{BSA}$ (yMt buffer). Mitochondria $\left(0.5 \mathrm{mg} \mathrm{ml}^{-1}\right)$ were incubate at $25^{\circ} \mathrm{C}$ in yMT buffer plus $4.2 \mathrm{mM}$ succinate. $\Delta \psi$ was measured by following the uptake of rhodamine 123 (Rh123) as described ${ }^{23}$. For detecting the release of cytochrome $c$, mitochondria were spun, and the supernatants and pellets were western-blotted with anti-yeast cytochrome $c$ antibodies.

Received 15 January; accepted 1 April 1999.

1. Thornberry, N. A. \& Lazebnik, Y Caspases: Enemies within. Science 281, 1312-1316 (1998).

2. Green, D. R. \& Reed, J. C. Mitochondria and apoptosis. Science 281, 1309-1312 (1998).

3. Merry, D. E. \& Korsmeyer, S. J. Bcl-2 gene family in the nervous system. Annu. Rev. Neurosci. 20, 245 267 (1997).

4. Adams, J. M. \& Cory, S. The Bcl-2 protein family: arbiters of cell survival. Science 281, 1322-1326 (1998).

5. Tsujimoto, Y. Role of Bcl-2 family proteins in apoptosis: apoptosomes or mitochondria? Genes to Cells 3, 697-707 (1998).

6. Jürgensmeier, J. M. et al. Bax directly induces release of cytochrome $\mathrm{c}$ from isolated mitochondria. Proc. Natl Acad. Sci. USA 95, 4997-5002 (1998).

7. Eskes, R. et al. Bax-induced cytochrome $c$ release from mitochondria is independent of the permeability transition pore but highly dependent on $\mathrm{Mg}^{2+}$ ions. J. Cell Biol. 143, 217-224 (1998).

8. Narita, M. et al. Bax interacts with the permeability transition pore to induce permeability transition and cytochrome $c$ release in isolated mitochondria. Proc. Natl Acad. Sci. USA 95, 14681-14686 (1998).

9. Marzo, I. et al. Bax and adenine nucleotide translocator cooperate in the mitochondrial control of apoptosis. Science 281, 2027-2031 (1998).

10. Bernardi, P., Broekemeier, K. M. \& Pfeiffer, D. R. Recent progress on regulation of the mitochondria permeability transition pore; a cyclosporin-sensitive pore in the inner mitochondrial membrane. $J$. Bioenerg. Biomembr. 26, 509-517 (1994).

11. Zoratti, M. \& Szabó, I. The mitochondrial permeability transition. Biochim. Biophys. Acta 1241, 139_ 176 (1995).

12. Colombini, M. Voltage gating in the mitochondrial channel, VDAC. J. Membr. Biol. 111, 103-111 (1989).

13. Antonsson, B. et al. Inhibition of Bax channel-forming activity by Bcl-2. Science 277, 370-372 (1997)

14. Minn, A. J. et al. Bcl- $\mathrm{x}_{\mathrm{L}}$ forms an ion channel in synthetic lipid membranes. Nature 385, 353-357 (1997).

15. Schendel, S. L. et al. Channel formation by antiapoptotic protein Bcl-2. Proc. Natl Acad. Sci. USA 94 5113-5118 (1997)

16. Schlesinger, P. H. et al. Comparison of the ion channel characteristics of proapoptotic Bax and antiapoptotic Bcl-2. Proc. Natl Acad. Sci. USA 94, 11357-11362 (1997).

17. Cheng, E. H., Levine, B., Boise, L. H., Thompson, C. B. \& Hardwick, J. M. Bax-independent inhibition of apoptosis by Bcl- $\mathrm{x}_{\mathrm{L}}$. Nature 379, 554-556 (1996).

18. Greenhalf, W., Stephan, C. \& Chaudhuri, B. Role of mitochondria and C-terminal membrane anchor of Bcl-2 in Bax induced growth arrest and mortality in Saccharomyces cerevisiae. FEBS Lett. 380, 169175 (1996).

19. Matsuyama, S., Xu, Q., Velours, J. \& Reed, J. C. The mitochondrial $\mathrm{F}_{\mathrm{O}} \mathrm{F}_{1}$-ATPase proton pump is required for function of the proapoptotic protein Bax in yeast and mammalian cells. Mol. Cell 1, 327336 (1998).

20. Blachly-Dyson, E., Peng, S., Colombini, M. \& Forte, M. Selectivity changes in site-directed mutants of the VDAC ion channel: structural implications. Science 247, 1233-1236 (1990).

21. Lee, A. C., Xu, X., Blachly-Dyson, E., Forte, M. \& Colombini, M. The role of yeast VDAC genes on the permeability of the mitochondrial outer membrane. J. Membr. Biol. 161, 173-181 (1998).

22. Mannella, C. A. Conformational changes in the mitochondrial channel protein, VDAC, and their functional implications. J. Struct. Biol. 121, 207-218 (1998).

23. Shimizu, S. et al. Bcl-2 prevents apoptotic mitochondrial dysfunction by regulating proton flux. Proc Natl Acad. Sci. USA 95, 1455-1459 (1998).

24. DePinto, V., Prezioso, G. \& Palmieri, F. A simple and rapid method for the purification of the mitochondrial porin from mammalian tissues. Biochem. Biophys. Acta 905, 499-502 (1987).

25. Rück, A., Dolder, M., Wallimann, T. \& Brdiczka, D. Reconstituted adenine nucleotide translocase forms a channel for small molecules comparable to the mitochondrial permeability transition pore. FEBS Lett. 426, 97-101 (1998).

26. Báthori, G., Sahin-Tóth, M., Fonyó, A. \& Ligeti, E. Transport properties and inhibitor sensitivity of isolated and reconstituted porin differ from those of intact mitochondria. Biochem. Biophys. Acto 1145, 168-176 (1993).

27. Kelvin, H. \& Fowlkes, B. J. in Current Protocols in Immunology 5.3.1-5.3.11 (Wiley Interscience, New York, 1990).

28. Daum, G., Bohni, P. C. \& Schatz, G. Import of proteins into mitochondria. Cytochrome b2 and cytochrome c peroxidase are located in the intermembrane space of yeast mitochondria. J. Biol. Chem. 257, 13028-13033 (1982).

Acknowledgements. We thank E. Margoliash, G. Schatz and H. H. Schmid for antibodies against pigeon cytochrome $c$, yeast cytochrome $c$, and rat ANT, respectively; M. Forte for VDAC1-deficient yeast (M222), its wild type (M3), and human $v d a c 1$ cDNA; J. M. Hardwick for Bcl- $\mathrm{x}_{\mathrm{L}}$ mutant cDNAs; M. Colombini for the polyanion; T. Chittenden for the expression plasmid for the GST-Bak fusion protein; and
N. Tsujimoto for editorial assistance. This study was supported by grants for Scientific Research on Priority Areas, for Center of Excellence Research and for Scientific Research, from the Ministry of Education, Science, Sports and Culture of Japan.

Correspondence and requests for materials should be addressed to Y.T. (e-mail: tsujimot@gene.med. osaka-u.ac.jp).

\section{Interaction of E1 and hSNF5 proteins stimulates replication of human papillomavirus DNA}

\section{Daeyoup Lee*, Hekwang Sohn*, Ganjam V. Kalpana $\dagger$ \& Joonho Choe*}

${ }^{*}$ Department of Biological Sciences, Korea Advanced Institute of Science and Technology, Taejon 305-701, Korea

$\dagger$ Department of Molecular Genetics, Albert Einstein College of Medicine, Bronx, New York 10461, USA

Mammalian viruses often use components of the host's cellular DNA replication machinery to carry out replication of their genomes, which enables these viruses to be used as tools for characterizing factors that are involved in cellular DNA replication. The human papillomavirus (HPV) E1 protein is essential for replication of the virus $\mathrm{DNA}^{1-3}$. Here we identify the cellular factor that participates in viral DNA replication by using a twohybrid assay ${ }^{4}$ in the yeast Saccharomyces cerevisiae and E1 protein as bait. Using this assay, we isolated Inil/hSNF5 (ref. 5), a component of the SWI/SNF complex which facilitates transcription by altering the structure of chromatin ${ }^{6}$. In vitro binding and immunoprecipitation confirmed that $\mathrm{E} 1$ interacts directly with

a

\begin{tabular}{|ll|}
\hline & HPV-18 E1 \\
\hline Met & 657
\end{tabular}

$\mathrm{pLexA} / 18 \mathrm{E}$

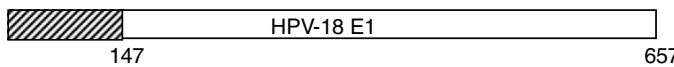

b

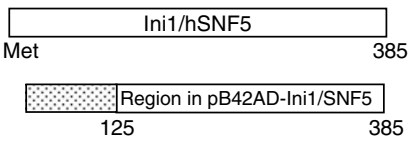

c

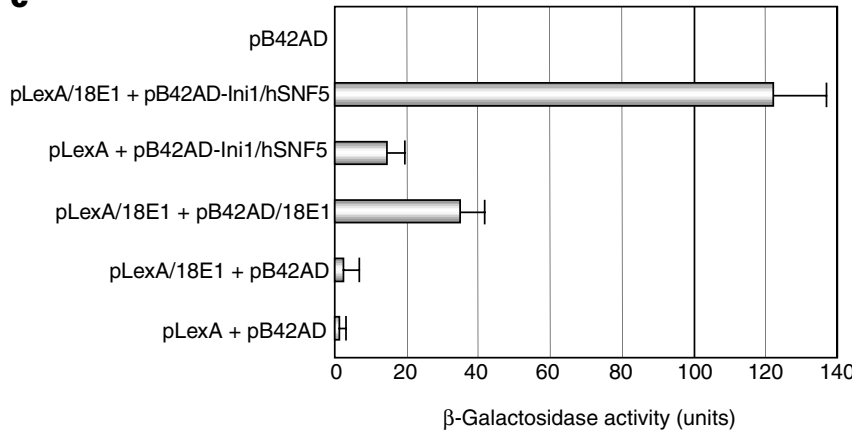

Figure 1 Interaction between HPV-18 E1 and Ini1/hSNF5 proteins. a, Structure of the pLexA/18E1 plasmid. Bar represents the LexA DNA binding domain for the LexA operator. b, Structure of pB42AD-Ini1/hSNF5. The dotted region represents an activation domain for a yeast promoter. c, Quantification of yeast two-hybrid interactions. Values represent the average for five different EGY48 colonies coexpressing the specified fusion proteins. Error bars indicate the standard deviation for each sample. 